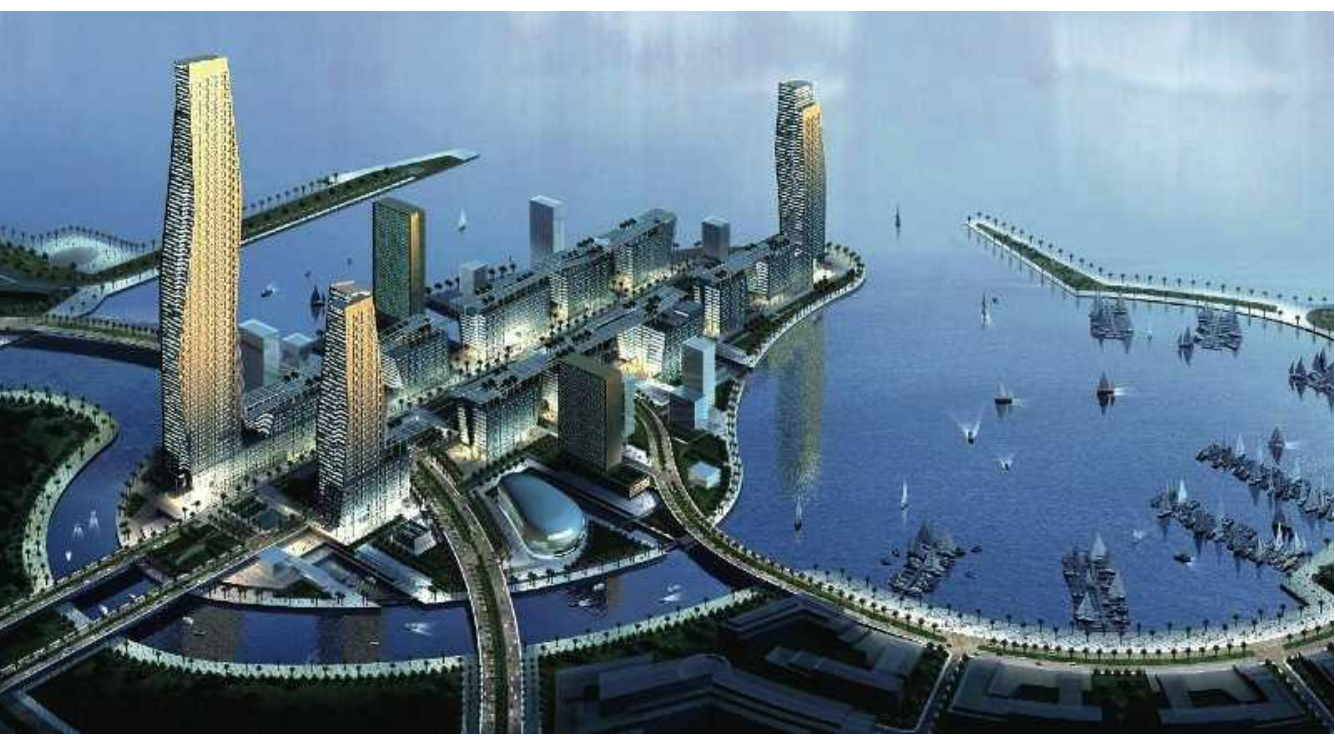

The King Abdullah Economic City will be home to a world-class research facility.

says Pier Giuseppe Pelicci, head of experimental oncology at the IEO.

Another difficulty, says Foiani, will be the problems that women researchers face in a country that allows them so little freedom of movement. "Culturally, it is another world," he says. But Manar Al-Moneef, head of SAGIA's life-sciences sector, says that she expects a "big improvement" in conditions for women soon. "Many more women are working in hospitals and research centres than a few years ago things are getting better rapidly," she says.

Saudi and Italian scientists will meet next month to sort out the details, and to identify the research programmes on which they will collaborate. One such programme could be breast cancer, says Foiani. The disease has a high priority in Saudi Arabia, where intermarriage within families has led to an above-average rate of breast cancers with unusual genetic mutations.

Financial arrangements for the initiative have not yet been negotiated. A few months ago SAGIA signed a \$5.3-billion deal with international partners, including Fraunhofer research institutes in Germany to develop BioSphere, a biotechnology science park planned for the Abdullah city.

Alison Abbott development of some cancers and the reaction to particular drugs. "Most of the data used in cancer studies are from Westerners," says Sumio Sugano, a genomics specialist at the University of Tokyo who attended the International Union against Cancer (UICC) symposium in Nanjing. "This is a chance to use Asian data."

The organizers anticipate difficulties stemming from concerns over the privacy of data. "We have to move one step at a time," says Sugano. "Building trust among researchers is the first step." Organizers of the meeting hope that the network's activities can bridge some of the animosity present in the historicaly fractious region. The meeting was funded by Japan's Ministry of Health, Labour and Welfare, partly to celebrate the 35th anniversary of normalization of Sino-Japanese diplomatic relations. The next meeting will be in Manila in March.

Norie Kawahara, a research fellow at the Research Center for Advanced Science and Technology at the University of Tokyo, says the site location, Nanjing, where hundreds of thousands of Chinese were massacred by the Japanese military 70 years ago - an event that is denied by some right-wing historians in Japan - was a symbolic choice.

A few years ago, when Kawahara started pushing the idea of a Japan-led Asian network, she says people refused, thinking that it sounded like a return to the Greater East Asian Co-Prosperity Sphere, the euphemistic name that Japan gave to its colonizing activities in the region. She hopes that through such activities as the anti-smoking, anti-cancer campaign she ran in a parallel session at last month's meeting, targeted at Chinese and Japanese children, she can "use science to rewrite history".

Tajima is applying for $¥ 60$ million (US\$542,000) over 3 years to push Japan's role as a hub for the network in the future. "But we won't need gigantic sums of money," says Malcolm Moore, head of the UICC Asia regional office in Bangkok. "What is needed is for people to get together and participate."

David Cyranoski
AMERICAN SOCIETY FOR CELL BIOLOGY Find meeting reports in our conference blog. http://blogs.nature. com/news

\section{Fund boost for German science}

Science was the big winner in Germany's budget, approved last week. The Christian Democrat-Social Democrat majority approved a record $9.8 \%$ increase in the federal budget for science and education for 2008.

The German coalition government had promised to boost investment in science and, almost uniquely for a budget proposal, this passed through parliament without any cuts. The Ministry for Education and Research (BMBF) will receive $€ 9.35$ billion (US $\$ 13.7$ billion) next year - a whopping $€ 150$ million more than the government had initially proposed in July.

Germany's research council, the DFG, which funds most university research, will see a $3 \%$ rise next year in its $€ 1$.6billion budget. Non-university research organizations, including the Max Planck Society, the Fraunhofer Society, which runs centres

for applied research, and the Helmholtz Association, which runs Germany's 15 national research centres, will also "It's good to see that awareness of the importance of science is on the rise." receive around $3 \%$ more money each. The BMBF also directly funds basic and applied science in fields of strategic importance, including health and climate research. Its grants will increase by $18 \%$ to $€ 3.5$ billion, including $€ 285$ million for winning universities in the government's 'excellence initiative' (see Nature 450, 452-453; 2007).

"This is a substantial growth," says Matthias Kleiner, the president of the DFG. "It's good to see that awareness of the importance of science is on the rise in Germany."

But although financial conditions for science have improved, scientific salaries in Germany are not internationally competitive, warns Rudi Balling, scientific director of the Helmholtz Centre of Infection Research in Braunschweig. "There's fresh money available to do many exciting things here, but we run the risk of losing the best people just because they can earn so much more abroad."

Quirin Schiermeier 